\title{
Phylogeny of the family Halomonadaceae based on 235 and 165 rDNA sequence analyses
}

1 Lehrstuhl für

Mikrobiologie, Technische

Universität München,

85350 Freising, Germany

2 Departamento de

Microbiología y

Parasitología, Facultad de

Farmacia, Universidad de

Sevilla, 41012 Seville, Spain

\author{
David R. Arahal, ${ }^{1,2}$ Wolfgang Ludwig, ${ }^{1}$ Karl H. Schleifer ${ }^{1}$ \\ and Antonio Ventosa ${ }^{2}$ \\ Author for correspondence: Antonio Ventosa. Tel: +34 954556765. Fax: + 34954628162. \\ e-mail:ventosa@us.es
}

\begin{abstract}
In this study, we have evaluated the phylogenetic status of the family Halomonadaceae, which consists of the genera Halomonas, Chromohalobacter and Zymobacter, by comparative 235 and 165 rDNA analyses. The genus Halomonas illustrates very well a situation that occurs often in bacterial taxonomy. The use of phylogenetic tools has permitted the grouping of several genera and species believed to be unrelated according to conventional taxonomic techniques. In addition, the number of species of the genus Halomonas has increased as a consequence of new descriptions, particularly during the last few years, but their features are too heterogeneous to justify their placement in the same genus and, therefore, a re-evaluation seems necessary. We have determined the complete sequences (about 2900 bases) of the 235 rDNA of 18 species of the genera Halomonas and Chromohalobacter and resequenced the complete 16S rDNA sequences of seven species of Halomonas. The results of our analysis show that two phylogenetic groups (respectively containing five and seven species) can be distinguished within the genus Halomonas. Six other species cannot be assigned to either of the above-mentioned groups. Furthermore, Halomonas marina forms a separate branch at a deeper level than the other species of the genus Halomonas, which suggests that it should be ascribed to a separate genus. The genus Chromohalobacter forms a monophyletic group constituted by Chromohalobacter marismortui, the recently reclassified species Chromohalobacter canadensis and Chromohalobacter israelensis and the recently proposed species Chromohalobacter salexigens. Finally, we propose to include the genus Carnimonas, with its single species Carnimonas nigrificans, in the family Halomonadaceae.
\end{abstract}

Keywords: Halomonadaceae, taxonomy, phylogeny, 23S and 16S rDNA sequences, moderately halophilic bacteria

\section{INTRODUCTION}

The family Halomonadaceae belongs to the $\gamma$-subclass of the Proteobacteria. It was proposed by Franzmann et al. (1988), according to results obtained with the $16 \mathrm{~S}$ rDNA cataloguing technique, to accommodate the moderately halophilic and marine bacteria of the genera Halomonas and Deleya. More recently, a study based on comparison of $16 \mathrm{~S}$ rDNA sequences from several moderately halophilic bacteria concluded that Chromohalobacter marismortui belongs to the family

The EMBL accession numbers for the 235 and 165 rDNA gene sequences reported in this paper are AJ306870-AJ306894.
Halomonadaceae and that Volcaniella eurihalina should be reclassified as Halomonas eurihalina (Mellado et al., 1995). In addition, these authors stated the need for a polyphasic approach to determine the natural taxonomic position of the species belonging to the genera Halomonas and Deleya, as well as Chromohalobacter marismortui, Halovibrio variabilis and Paracoccus halodenitrificans. In addition, Dobson \& Franzmann (1996) carried out a similar study and proposed that the genera Halomonas and Deleya, as well as the species Halovibrio variabilis and Paracoccus halodenitrificans, were unified into the single genus Halomonas. At the same time, the genus Zymobacter became the third genus to be included in the family 
Table 1. Bacterial species used in this study, their sources and rDNA sequence information

Culture collections are abbreviated as: ACAM, Australian Collection of Antarctic Micro-organisms; ATCC, American Type Culture Collection; CCM, Czech Collection of Microorganisms; CECT, Colección Española de Cultivos Tipo; DSM, Deutsche Sammlung von Mikroorganismen und Zellkulturen; IAM, Institute of Applied Microbiology; NCIMB, National Collections of Industrial Food and Marine Bacteria; UQM, University of Queensland Microbial Culture Collection.

\begin{tabular}{|c|c|c|c|c|}
\hline \multirow[t]{2}{*}{ Species } & \multirow[t]{2}{*}{ Type strain designation(s) } & \multirow[t]{2}{*}{ Original source } & \multicolumn{2}{|c|}{ Sequence accession nos (bp) } \\
\hline & & & 16S rRNA & 23S rRNA \\
\hline Carnimonas nigrificans & CECT $4437^{\mathrm{T}} ; \mathrm{CTCBS}^{\mathrm{T}}$ & Cured meat products & Y13299 (1519) & - \\
\hline Chromohalobacter canadensis & $\begin{array}{l}\text { ATCC } 43984^{\mathrm{T}} ; \text { NRCC } 41227^{\mathrm{T}} ; \\
\text { DSM } 6769^{\mathrm{T}}\end{array}$ & Medium contaminant (Canada) & AJ295143 (1532) & AJ306870 (2910) \\
\hline Chromohalobacter israelensis & ATCC $43985^{\mathrm{T}} ; \mathrm{Ba}_{1}{ }^{\mathrm{T}} ;$ DSM $6768^{\mathrm{T}}$ & Dead Sea & AJ295144 (1532) & AJ306871 (2909) \\
\hline Chromohalobacter marismortui & $\begin{array}{l}\text { ATCC } 17056^{\mathrm{T}} ; \text { CCM } 3518^{\mathrm{T}} \\
\text { DSM } 6770^{\mathrm{T}}\end{array}$ & Dead Sea & X87219 (1423) & AJ306872 (2998) \\
\hline Chromohalobacter salexigens & DSM $3043^{\mathrm{T}} ; 1 \mathrm{H} 11^{\mathrm{T}} ;$ CECT $5384^{\mathrm{T}}$ & Solar saltern (Bonaire, Netherlands Antilles) & AJ295146 (1531) & AJ306873 (2908) \\
\hline Halomonas aquamarina & $\begin{array}{l}\text { IAM } 12550^{\mathrm{T}} ; \text { ATCC } 14400^{\mathrm{T}} \\
\text { DSM } 30161^{\mathrm{T}}\end{array}$ & Marine water (Hawaii, USA) & $\begin{array}{l}\text { M93352 (1466); } \\
\text { AJ306888 (1528) }\end{array}$ & AJ306874 (2914) \\
\hline Halomonas campisalis & ATCC $700597^{\mathrm{T}} ; 4 \mathrm{~A}^{\mathrm{T}}$ & Alkali lake sediment (Washington, USA) & AF054286 (1400) & - \\
\hline Halomonas cupida & ATCC $27124^{\mathrm{T}} ; 79^{\mathrm{T}} ;$ DSM $4740^{\mathrm{T}}$ & Marine water (Hawaii, USA) & L42615 (1471) & AJ306875 (2910) \\
\hline Halomonas desiderata & DSM $9502^{\mathrm{T}} ; \mathrm{FB}^{\mathrm{T}}$ & Sewage treatment plant (Göttingen, Germany) & X92417 (1495) & AJ306876 (2910) \\
\hline Halomonas elongata & ATCC $33173^{\mathrm{T}} ; 1 \mathrm{H} 9^{\mathrm{T}} ;$ DSM $2581^{\mathrm{T}}$ & Solar saltern (Bonaire, Netherlands Antilles) & $\begin{array}{l}\text { M93355 (1479); } \\
\text { X67023 (1470) }\end{array}$ & AJ306877 (2910) \\
\hline Halomonas eurihalina & ATCC $49336^{\mathrm{T}} ;$ F9-6 $6^{\mathrm{T}} ;$ DSM $5720^{\mathrm{T}}$ & Saline soil (Alicante, Spain) & $\begin{array}{l}\mathrm{L} 42620(1490) \\
\text { X87218 }\end{array}$ & AJ306878 (2911) \\
\hline Halomonas halmophila & $\begin{array}{l}\text { NCIMB } 1971^{\mathrm{T}} ; \text { DSM } 5349^{\mathrm{T}} ; \\
\text { ATCC } 19717^{\mathrm{T}}\end{array}$ & Dead Sea & $\begin{array}{l}\text { M59153 (1540); } \\
\text { AJ306889 (1530) }\end{array}$ & AJ306879 (2920) \\
\hline Halomonas halodenitrificans & $\begin{array}{l}\text { ATCC } 13511^{\mathrm{T}} ; \text { CCM } 286^{\mathrm{T}} ; \\
\text { DSM } 735^{\mathrm{T}}\end{array}$ & Meat-curing brines & L04942 (1531) & - \\
\hline Halomonas halodurans & ATCC $29686^{\mathrm{T}} ;$ DSM $5160^{\mathrm{T}}$ & Great Bay Estuary (New Hampshire, USA) & L42619 (1474) & - \\
\hline Halomonas halophila & CCM $3662^{\mathrm{T}} ; \mathrm{F} 5-7^{\mathrm{T}} ; \mathrm{DSM} 4770^{\mathrm{T}}$ & Saline soil (Alicante, Spain) & M93353 (1478) & - \\
\hline Halomonas magadiensis & NCIMB $13595^{\mathrm{T}} ; 21 \mathrm{M} 1^{\mathrm{T}}$ & East African alkaline lakes sediments & X92150 (1473) & - \\
\hline Halomonas marina & ATCC $25374^{\mathrm{T}} ; 219^{\mathrm{T}} ; \mathrm{DSM} 4741^{\mathrm{T}}$ & Marine water (Hawaii, USA) & $\begin{array}{l}\text { M93354 (1483); } \\
\text { AJ306890 (1536) }\end{array}$ & AJ306880 (2910) \\
\hline Halomonas meridiana & $\begin{array}{l}\text { ACAM } 246^{\mathrm{T}} \text {; UQM } 3352^{\mathrm{T}} \text {; } \\
\text { DSM } 5425^{\mathrm{T}}\end{array}$ & Hypersaline lakes (Antarctica) & $\begin{array}{l}\text { M93356 (1475); } \\
\text { AJ306891 (1528) }\end{array}$ & AJ306881 (2914) \\
\hline Halomonas pacifica & ATCC $27122^{\mathrm{T}} ; 62^{\mathrm{T}} ;$ DSM $4742^{\mathrm{T}}$ & Marine water (Hawaii, USA) & L42616 (1480) & AJ306882 (2910) \\
\hline Halomonas pantelleriensis & DSM $9661^{\mathrm{T}} ; \mathrm{AAP}^{\mathrm{T}}$ & Hard sand (Panterellia, Italy) & X93493 (1477) & AJ306883 (2912) \\
\hline Halomonas salina & $\begin{array}{l}\text { ATCC } 49509^{\mathrm{T}} ; \mathrm{F} 8-11^{\mathrm{T}} ; \\
\text { DSM } 5928^{\mathrm{T}}\end{array}$ & Saline soils (Alicante, Spain) & $\begin{array}{l}\text { L42617 (1443); } \\
\text { X87217 (1478); } \\
\text { AJ243447 (1493); } \\
\text { AJ243448 (1493); } \\
\text { AJ295145 (1532) }\end{array}$ & AJ306884 (2908) \\
\hline
\end{tabular}


Halomonadaceae (Dobson \& Franzmann, 1996). At the time of writing, there were 19 validly published species within the genus Halomonas, while Chromohalobacter and Zymobacter respectively contained four and one species. These species and their origins are listed in Table 1, in which a closely related organism, Carnimonas nigrificans (Garriga et al., 1998), that perhaps could be considered a member of the family Halomonadaceae, has been included. A full chronological record of the contributions to the taxonomy of this group of bacteria (Euzéby, 1997) reveals that more than half of the species have been reclassified at least once and their nomenclature was changed. In most cases, the experimental basis for these changes was comparison of the $16 \mathrm{~S}$ rDNA sequences.

In our study, we have carried out a re-evaluation of the phylogeny of the species of Halomonadaceae using comparative sequence analysis of $23 \mathrm{~S}$ and $16 \mathrm{~S}$ rDNA. For this purpose, eight already available 16S rDNA sequences of type strains were resequenced to resolve undetermined positions and 18 new complete $23 \mathrm{~S}$ rDNA sequences were obtained.

Over a period of only a few years, comparative sequence analysis of the small-subunit rRNA has become a major source for phylogenetic studies of micro-organisms. This is reflected in the literature and in the continually expanding number of freely accessible sequences, more than 16000 at the time of writing. In contrast, this number is much lower for the 23S rDNA (only about 500), despite it being more informative. In many cases, only partial sequences, alone or together with the $16 \mathrm{~S}-23 \mathrm{~S}$ rDNA intergenic spacer, are determined. Although partial sequences can be sufficient for bacterial identification, they should not be used for inferring phylogeny since incorrect conclusions may be drawn (Ludwig \& Schleifer, 1995). Thus, there are not many examples of full 23S rDNA sequence-based phylogeny, such as those from Briones \& Amils (2000), Ludwig et al. (1992, 1995), Martínez-Murcia et al. (1993) and Sallen et al. (1996). In our study, we have used this approach to determine in detail the phylogenetic relationship of species of the genera of the family Halomonadaceae and to clarify the classification of this heterogeneous bacterial group.

\section{METHODS}

Bacterial strains and cultivation conditions. The strains used in this study are listed in Table 1. The recommended media and growth conditions for each strain were used.

Extraction of total DNA. Two millilitres of a culture of exponentially growing cells was collected from broth cultures by centrifugation at $12000 \mathrm{~g}$ for $2 \mathrm{~min}$. The pellets were washed with saline EDTA $(0.15 \mathrm{M} \mathrm{NaCl}, 0.1 \mathrm{M}$ EDTA, pH 8.0) and suspended in $500 \mu \mathrm{l}$ saline EDTA. Proteinase $\mathrm{K}\left(2 \mu \mathrm{l}, 20 \mathrm{mg} \mathrm{ml}^{-1}\right)$ was added and an incubation step was performed at $37^{\circ} \mathrm{C}$ for $45 \mathrm{~min}$. This was followed by a second incubation, after the addition of $40 \mu 125 \%$ (w/v) SDS, this time at $60^{\circ} \mathrm{C}$ for $10 \mathrm{~min}$. Next, $180 \mu \mathrm{l} \mathrm{M}$ 

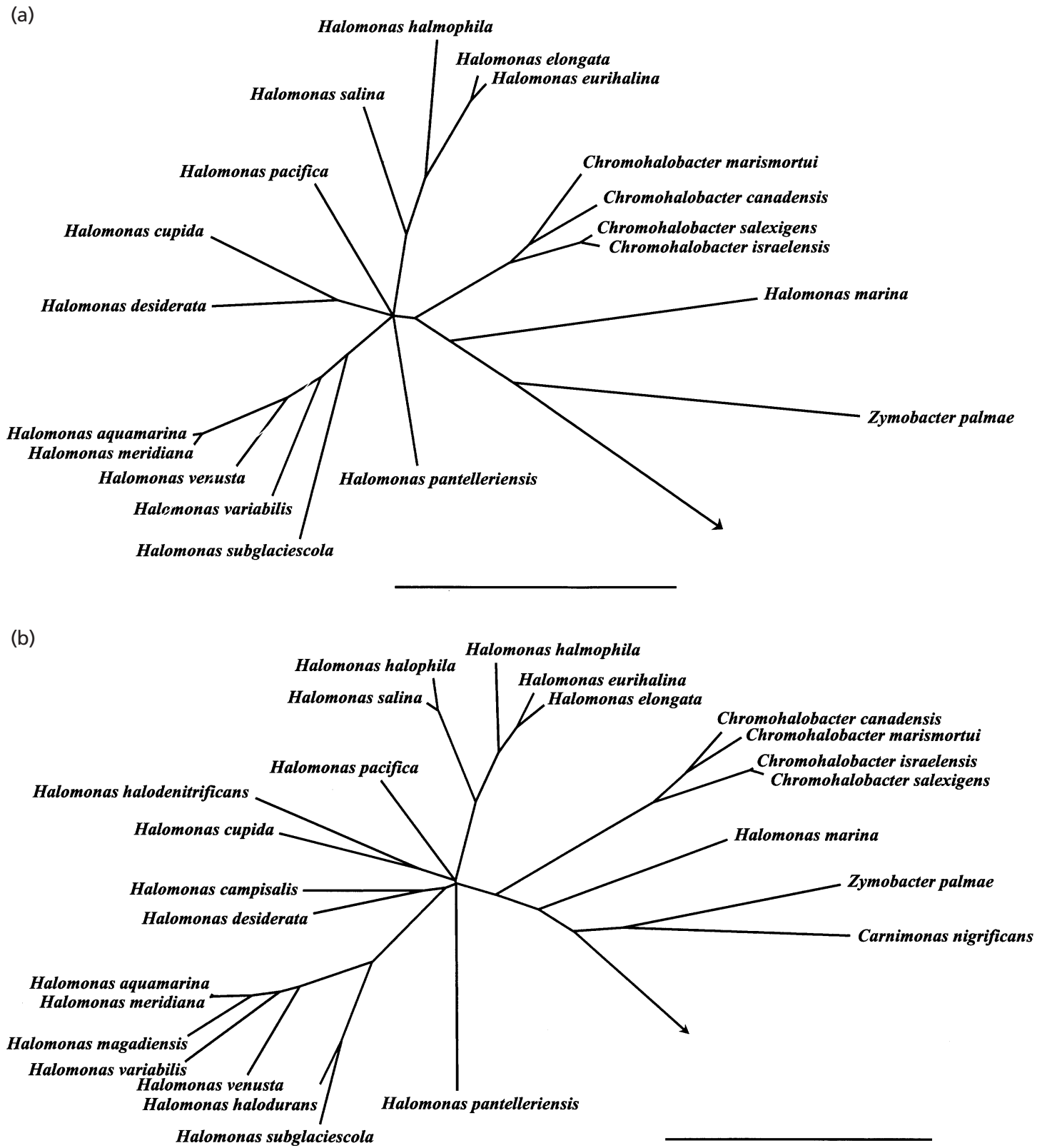

Fig. 1. Phylogenetic consensus trees of members of the genera Halomonas, Chromohalobacter, Zymobacter and Carnimonas constructed using $23 \mathrm{~S}$ rRNA sequences (a) and $16 \mathrm{~S}$ rDNA sequences (b). The arrows point to the outgroups, which have been removed to simplify the figure. Bars, $5 \%$ estimated sequence divergence.

sodium acetate and $745 \mu$ chloroform/isoamyl alcohol (24: 1) were added. The contents of the tubes were mixed gently and centrifuged for $2 \mathrm{~min}$. After collecting the aqueous fraction, 2 vols cold ethanol was added to precipitate the DNA and the mixture was kept at $-20^{\circ} \mathrm{C}$ for at least 10 min. The precipitated DNA was then centrifuged and washed with $70 \%$ cold ethanol. Finally, the DNA was dissolved in redistilled water and checked by agarose gel electrophoresis.

235 and 16S rDNA gene amplification and sequencing. Approximately $10 \mathrm{ng}$ total DNA was used for PCR amplification with the Taq PCR Core kit (Qiagen) following the recommendations of the manufacturer. Amplicons were checked by agarose gel electrophoresis and cleaned with the
QIAquick PCR purification kit (Qiagen). For each microorganism, two fragments were amplified, one from position 8 of the 16S rDNA to position 2669 of the 23S rDNA (Escherichia coli numbering) and another from position 1091 of the $23 \mathrm{~S}$ rDNA to the beginning of the $5 \mathrm{~S}$ rDNA (Table 2). The first of these PCR products was used to sequence most of the $23 \mathrm{~S}$ rDNA ( $5^{\prime}$ end) and, in some cases, also the full $16 \mathrm{~S}$ rDNA. The second amplicon was used to reach the $3^{\prime}$ end of the $23 \mathrm{~S}$ rDNA sequence. Sequencing was performed with a LICOR automated sequencer (MWG Biotech) using the Thermo Sequenase fluorescent-labelled primer sequencing kit (Amersham Pharmacia Biotech).

Phylogenetic analyses. 23S and 16S rDNA sequences analyses were performed separately, with the aid of the ARB 
software package (Ludwig \& Strunk, 1996). In the first case, about 500 complete or almost complete 23S rDNA sequences were available for the analysis, while this number was greater than 16000 in the case of the 16S rDNA sequences.

For the phylogenetic trees presented in Fig. 1, only sequences from the type strains of species whose names have been validly published were taken into account. When more than one sequence was available (Table 1), the most complete one was used. A distance matrix was obtained using a large number of outgroup sequences. The distance values were corrected for multiple base changes at single positions by the formula of Jukes \& Cantor (1969) and a tree was reconstructed by applying the neighbour-joining method of Saitou $\&$ Nei (1987). The application of other treeing methods (maximum-parsimony and maximum-likelihood) allowed a collection of trees to be obtained that were compared to make an estimation of the confidence. Thus, collapsed branches in Fig. 1 indicate that the nodes affected showed more than one possible topology, whereas bifurcated branches are those that maintained their relative topology in all trees examined.

\section{RESULTS AND DISCUSSION}

In this study, we have determined the complete $23 \mathrm{~S}$ rDNA sequences of 18 type strains and the complete $16 \mathrm{~S}$ rDNA sequences of seven type strains (the previously available sequences of these strains contained several ambiguous positions) of members of the family Halomonadaceae. Following the recommendations of Ludwig et al. (1998), a combination of different treeing methods and filters was used for analysis of the $23 \mathrm{~S}$ and $16 \mathrm{~S}$ rDNA sequences. The trees presented in Fig. 1 synthesize the topologies obtained in each separate analysis. Only robust branches have been kept, while those affected by the methodology have been collapsed to form multifurcations.

As expected, there was good agreement between the $23 \mathrm{~S}$ rDNA- and 16S rDNA-derived trees. Some minor differences can be detected, but it is also important to mention that the two datasets are not equivalent, since fewer $23 \mathrm{~S}$ rDNA sequences are available. In contrast, for some species, more than one $16 \mathrm{~S}$ rDNA sequence was available. Some of them were obtained in this study (Table 1). For the final analysis, the most complete sequences were used.

Several conclusions can be extracted from our phylogenetic analysis based on the 23S and 16S rDNA sequence comparison. Firstly, the genus Halomonas is not monophyletic and two phylogenetic groups are distinguishable. Group 1 comprises the type species, Halomonas elongata, and four other species, Halomonas eurihalina, Halomonas halmophila, Halomonas halophila and Halomonas salina. The mean 16S rDNA sequence similarity for this group was $98 \cdot 2 \%$. The same value was obtained with the $23 \mathrm{~S}$ rDNA sequences. Group 2 is formed by the following species: Halomonas aquamarina, Halomonas meridiana, Halomonas magadiensis, Halomonas variabilis, Halomonas venusta, Halomonas halodurans and Halomonas sub- glaciescola. The mean 16S/23S rDNA sequence similarity for this group was 97.4 and $97.6 \%$, respectively. The species Halomonas pacifica, Halomonas halodenitrificans, Halomonas cupida, Halomonas desiderata, Halomonas campisalis and Halomonas pantelleriensis did not fall clearly into either of the two groups mentioned above and did not form a group themselves. They shared relatively low values of sequence similarity with the strains included in groups 1 and $2(91.7-96.4 \%$ for $16 \mathrm{~S}$ rDNA sequences and $92.9-95.2 \%$ for $23 \mathrm{~S}$ rDNA). Among themselves, the values are only slightly higher: 93.6-96.7\% (16S rDNA) and $95 \cdot 2-96 \cdot 4 \%$ (23S rDNA). These results are in agreement with the phenotypic heterogeneity reported for the species of the genus Halomonas. Furthermore, there are other features that clearly support the need to clarify the current classification of the species of the genus Halomonas. The $\mathrm{G}+\mathrm{C}$ content of the genus ranges from 52 to $68 \mathrm{~mol} \%$, a range too wide if we consider that it is generally accepted that $\mathrm{G}+\mathrm{C}$ contents of members of the same genus should not differ by more than $10 \mathrm{~mol} \%$ (Owen \& Pitcher, 1985).

A phylogenetic group closely related to Halomonas is that of Chromohalobacter marismortui, which also includes Halomonas canadensis and Halomonas israelensis, recently proposed as members of the genus Chromohalobacter (Arahal et al., 2001a), and the newly proposed species Chromohalobacter salexigens (Arahal et al., 2001b). The mean 23S/16S rDNA similarity of this genus is $98 \cdot 6 / 98 \cdot 5 \%$. In the consensus tree derived from the $23 \mathrm{~S}$ rDNA, the node that clusters this genus is separate from that containing all Halomonas species, with the only exception of Halomonas marina, which always forms a deeper branching. The $23 \mathrm{~S} / 16 \mathrm{~S}$ rDNA sequence similarities of this organism to any of the Halomonas or Chromohalobacter species respectively ranged from 91.8 to $94.9 \%$ and 90.9 to $93.0 \%$, i.e. lower than $95 \%$ in all cases, which is generally accepted as a reference value for genus separation (Ludwig et al., 1998). Similarly, low values were obtained between the sequences of Halomonas marina and those of Zymobacter palmae and Carnimonas nigrificans. The affiliation of the marine organism Halomonas marina has changed since its description (Cobet et al., 1970) and it has been included in several genera (Arthrobacter, Pseudomonas, Deleya and Halomonas). Given these results, a reconsideration of the taxonomic status of Halomonas marina seems necessary.

Our phylogenetic study supports the inclusion of the genus Carnimonas in the family Halomonadaceae. In the original description of the single species Carnimonas nigrificans (Garriga et al., 1998), this possibility was rejected mainly because the 16S rDNA sequence signatures showed two differences from those described by Dobson \& Franzmann (1996). However, we consider that there are several convincing reasons that support its inclusion. Firstly, it forms a very stable cluster with Zymobacter palmae. When the 16S rDNA 
Table 2. Amplification and sequencing primers used in this study

Each forward amplification primer was used together with the reverse primer below it in the table. Sequencing primers were marked for infrared detection at the $5^{\prime}$ end. Sequences are listed according to the IUPAC code for nucleotide ambiguities. Primer positions are given according to the $E$. coli numbering.

\begin{tabular}{|llcl|}
\hline \multicolumn{1}{|c}{ Primer } & \multicolumn{1}{c}{ Sequence } & Position & \multicolumn{1}{c|}{ Use } \\
\hline 616Valt & AGAGTTTGATYMTGGCTCAG & $8-27(16 \mathrm{~S}$ rRNA) & Amplification, Forward \\
985R & CCGGTCCTCTCGTACT & 2654-2669(23S rRNA) & Amplification, Reverse \\
1023V & GCGTAAYAGCTCACT & $1091-1105(23 \mathrm{~S}$ rRNA) & Amplification, Forward \\
504R & SWGTTCGRVAWGGGA & $35-49(5 \mathrm{~S}$ rRNA $)$ & Amplification, Reverse \\
609RIII1 & ACTACCVGGGTATCTAA & $788-804$ & Sequencing, 16S rRNA \\
606RIII & CCCGRGAACGYATTCAC & $1371-1378$ & Sequencing, 16S rRNA \\
609VIII2 & AACAGGHTTAGATACCC & $781-797$ & Sequencing, 16S rRNA \\
992IRry97 & TTCCCTCACRGTACT & $457-471$ & Sequencing, 23S rRNA \\
1020IRrmz98 & TCTGGGYTGTTCCC & $975-990$ & Sequencing, 23S rRNA \\
992IRvm97 & AGTACCGTGAGGRAA & $457-471$ & Sequencing, 23S rRNA \\
1019IRvm97 & TAGCTGGTTCTYYCCGAA & $803-820$ & Sequencing, 23S rRNA \\
1037IRrm97 & CTTACCCGACAAGGAATTTCG & $1934-1954$ & Sequencing, 23S rRNA \\
987IRry97 & CTTAGATGCNTTCAG & $2745-2759$ & Sequencing, 23S rRNA \\
1027VIR & AAACCGACACAGGTRG & $1608-1623$ & Sequencing, 23S rRNA \\
328IRvm97 & TCCTAAGGTAGCGAAATTCCTTG & $1923-1945$ & Sequencing, 23S rRNA \\
1042GPHI & GTTTGGCACCTCGATGTCGRCTC & $2490-2512$ & Sequencing, 23S rRNA \\
\hline
\end{tabular}

sequences of Carnimonas nigrificans and Zymobacter palmae are compared with those of the species of the genera Halomonas and Chromohalobacter, the similarity values are always quite high and, in most cases, even higher for the Carnimonas nigrificans 16S rDNA sequence.

The family Halomonadaceae was defined initially on the basis of 19 16S rDNA signatures (Dobson et al., 1993), but this was later reduced in four so that Zymobacter palmae could be included in the description of the family (Dobson \& Franzmann, 1996). For the remaining 15 signatures, Carnimonas nigrificans differs in two residues, at positions 484 and 486, while Zymobacter palmae differs in none. But when the original 19 residues are checked, Zymobacter palmae shows four differences and Carnimonas nigrificans five, three of which (at positions 1424, 1439 and 1462) are identical in both species. Therefore, the requirement of having all 19 signatures is met only by the species of Halomonas (including Halomonas marina) and Chromohalobacter. Zymobacter palmae and Carnimonas nigrificans exhibit an almost equivalent number of mismatches (some of them coincident), reflecting, with some limitations, as we observe in Fig. 1, that the two genera are closely related and may have evolved from a common ancestor of Halomonas-Chromohalobacter sensu lato.

We therefore propose the inclusion of the genus Carnimonas in the family Halomonadaceae. A new description of the family is unnecessary, since the phenotypic traits of Carnimonas nigrificans are compatible with those reported for members of this family. Carnimonas nigrificans has been described as being able to grow with up to $8-10 \%$ salts (Garriga et al., 1998), which is lower than the maximum salt concentration that allows growth of most species of the genera Halomonas and Chromohalobacter. The salinity range of Zymobacter palmae has not yet been reported.

The 16S rDNA sequence signatures of the family Halomonadaceae could be redefined to consist of 13 elements common to all members plus six residues with two possible bases. These are: 484 (A or G), 486 (C or $\mathrm{U}), 1424$ (C or U), 1439 (C or U), 1462 (A or C) and 1464 (C or U).

The possibility of splitting the genus Halomonas into two or more genera is tempting, but has to be considered carefully to avoid excessive and unnecessary renaming. Besides, such a proposal should be accompanied by phenotypic or chemotaxonomic data. We have carried out a compilation of phenotypic features of the species included in our study for comparative purposes, but only a small fraction of these traits have been described for more than $80 \%$ of the species (Table 3). In Table 3, the species have been grouped according to the results of the phylogenetic analysis. From these data, it can be concluded that there is not sufficient evidence to differentiate the phylogenetic groups within the genus Halomonas. Even for the species Halomonas marina, for which the phylogenetic evidence of separate generic status is strong, it is not possible to provide an unequivocal phenotypic description that differentiates it from the other members of the family Halomonadaceae.

Nevertheless, the recognition of the phylogenetic groups as presented here may help to understand this 
Table 3. Differential features among the members of the family Halomonadaceae

Taxa are listed as: 1, Halomonas elongata; 2, Halomonas eurihalina; 3, Halomonas halmophila; 4, Halomonas halophila; 5, Halomonas salina; 6, Halomonas aquamarina; 7 , Halomonas meridiana; 8, Halomonas magadiensis; 9, Halomonas variabilis; 10, Halomonas venusta; 11, Halomonas halodurans; 12, Halomonas subglaciescola; 13,

Halomonas pacifica; 14, Halomonas halodenitrificans; 15, Halomonas cupida; 16, Halomonas desiderata; 17, Halomonas campisalis; 18, Halomonas pantelleriensis; 19,

Halomonas marina; 20, Chromohalobacter marismortui; 21, Chromohalobacter canadensis; 22, Chromohalobacter israelensis; 23, Chromohalobacter salexigens; 24,

Zymobacter palmae; 25, Carnimonas nigrificans. Data were taken from Akagawa \& Yamasato (1989), Arahal et al. (2001a, b), Baumann et al. (1972), Berendes et al.

(1996), Davis et al. (1969), Dobson et al. (1990), Duckworth et al. (2000), Fendrich (1988), Franzmann et al. (1987), Garriga et al. (1998), Hebert \& Vreeland (1987),

Huval et al. (1995), James et al. (1990), Mormile et al. (1999), Okamoto et al. (1993), Quesada et al. (1984, 1990), Romano et al. (1996), Rosenberg (1983), Valderrama et al. (1991), Ventosa et al. (1989), Vreeland et al. (1980) and this study. Characters are scored as: +, positive; -, negative; ND, not determined; d, differs among studies.

\begin{tabular}{|c|c|c|c|c|c|c|c|c|c|c|c|c|c|c|c|c|c|c|c|c|c|c|c|c|c|}
\hline \multirow[t]{2}{*}{ Characteristic } & \multicolumn{5}{|c|}{ Halomonas rDNA group 1} & \multicolumn{7}{|c|}{ Halomonas rDNA group 2} & \multicolumn{7}{|c|}{ Ungrouped Halomonas } & \multicolumn{6}{|c|}{ Chromohalobacter } \\
\hline & 1 & 2 & 3 & 4 & 5 & 6 & 7 & 8 & 9 & 10 & 11 & 12 & 13 & 14 & 15 & 16 & 17 & 18 & 19 & 20 & 21 & 22 & 23 & 24 & 25 \\
\hline Morphology & Rods & Rods & $\begin{array}{l}\text { Short } \\
\text { rods }\end{array}$ & $\begin{array}{l}\text { Short } \\
\text { rods }\end{array}$ & Rods & Rods & Rods & Rods & $\begin{array}{l}\text { Curved } \\
\text { rods }\end{array}$ & Rods & $\begin{array}{l}\text { Short } \\
\text { rods }\end{array}$ & Rods & Rods & $\begin{array}{l}\text { Short } \\
\text { rods }\end{array}$ & Rods & Rods & Rods & Rods & Rods & Rods & Rods & Rods & Rods & Rods & $\begin{array}{l}\text { Short } \\
\text { rods }\end{array}$ \\
\hline Cell length $(\mu \mathrm{m})$ & $\mathrm{ND}$ & $2 \cdot 0-2 \cdot 5$ & $0 \cdot 9-1 \cdot 3$ & $1 \cdot 5-2 \cdot 0$ & $2 \cdot 0-2 \cdot 5$ & $4 \cdot 0-6 \cdot 0$ & $1 \cdot 9-4 \cdot 5$ & $4 \cdot 0-6 \cdot 0$ & $1 \cdot 0-3 \cdot 0$ & $\mathrm{ND}$ & $1 \cdot 5-2 \cdot 0$ & 5-10 & ND & $0 \cdot 9-1 \cdot 2$ & $\mathrm{ND}$ & $1 \cdot 0-2 \cdot 6$ & $3-5$ & $1 \cdot 4-2 \cdot 6$ & $1 \cdot 6-4 \cdot 0$ & $1 \cdot 5-4 \cdot 0$ & $2 \cdot 0-3 \cdot 8$ & $1 \cdot 5-4 \cdot 2$ & $2 \cdot 0-3 \cdot 0$ & $1 \cdot 3-2 \cdot 4$ & $1 \cdot 0-1 \cdot 7$ \\
\hline Cell width $(\mu \mathrm{m})$ & $\mathrm{ND}$ & $0 \cdot 8-1 \cdot 0$ & $0 \cdot 3-0 \cdot 6$ & $0.5-0.7$ & $0.7-0.8$ & $0.4-0.8$ & $0 \cdot 6-1 \cdot 0$ & $0.6-0.8$ & $0.5-0.8$ & $\mathrm{ND}$ & $0.4-0.6$ & $0 \cdot 5-1 \cdot 1$ & ND & $0.5-0.9$ & $\mathrm{ND}$ & $0.4-0.6$ & 1 & $0.4-0.7$ & $0 \cdot 8-1 \cdot 2$ & $0 \cdot 6-1 \cdot 0$ & $0 \cdot 6-1 \cdot 2$ & $0 \cdot 6-0 \cdot 9$ & $0 \cdot 7-1 \cdot 0$ & $0 \cdot 7-0.9$ & $0 \cdot 5-0 \cdot 6$ \\
\hline Motility & + & - & + & + & - & + & + & + & + & + & + & + & + & - & + & + & + & + & + & + & + & + & + & + & - \\
\hline $\begin{array}{l}\text { Flagellar } \\
\text { arrangement* }\end{array}$ & $\mathrm{L}-\mathrm{P}$ & - & $\mathrm{L}$ & $\mathrm{Pe}$ & - & $\mathrm{Pe}$ & $\mathrm{L}$ & ND & $\mathrm{P}$ & $\mathrm{Pe}$ & $\mathrm{P}$ & $\mathrm{Pe}$ & $\mathrm{Pe}$ & - & $\mathrm{Pe}$ & $\mathrm{Pe}$ & $\mathrm{ND}$ & $\mathrm{ND}$ & P & $\mathrm{Pe}$ & P & P & $\mathrm{L}-\mathrm{P}$ & $\mathrm{Pe}$ & - \\
\hline Pigmentation & None & Cream & White & Cream & $\begin{array}{l}\text { Yellow- } \\
\text { cream }\end{array}$ & None & White & $\begin{array}{c}\text { Cream- } \\
\text { beige }\end{array}$ & Cream & ND & None & Cream & ND & Cream & $\mathrm{ND}$ & None & $\mathrm{ND}$ & $\begin{array}{c}\text { Cream- } \\
\text { pink }\end{array}$ & Cream & $\begin{array}{c}\text { Brown- } \\
\text { yellow }\end{array}$ & White & Cream & $\begin{array}{c}\text { White- } \\
\text { cream }\end{array}$ & White & White \\
\hline $\begin{array}{l}\text { Facultative } \\
\text { anaerobe }\end{array}$ & + & - & - & - & - & - & - & - & - & $\mathrm{ND}$ & - & - & ND & + & $\mathrm{ND}$ & + & + & - & $\mathrm{ND}$ & - & - & - & + & + & - \\
\hline Salt range (\%) & $3 \cdot 5-20$ & $5-20$ & $0 \cdot 5-20$ & $2-30$ & $2 \cdot 5-20$ & $0-20$ & $1-20$ & $0-20$ & $7-30$ & ND & $3 \cdot 5-20$ & $0 \cdot 5-20$ & ND & $3-20$ & ND & $0-18$ & $1-26$ & $1 \cdot 2-15$ & $2-12$ & $2-30$ & $3-25$ & $3 \cdot 5-20$ & $0 \cdot 9-25$ & ND & $<10$ \\
\hline $\begin{array}{l}\text { Temperature } \\
\text { range }\left({ }^{\circ} \mathrm{C}\right)\end{array}$ & $15-45$ & $15-45$ & $20-45$ & $15-45$ & $10-45$ & $5-40$ & $0-55$ & $25-40$ & $15-37$ & $4-40$ & $4-35$ & $0-25$ & $5-45$ & $0-32$ & $5-40$ & $10-45$ & $4-50$ & $10-44$ & $4-35$ & $5-45$ & $15-45$ & $15-45$ & $4-45$ & $21-39$ & $5-37$ \\
\hline $\mathrm{pH}$ range & $5-9$ & $5-10$ & $5-9$ & $5-10$ & $5-10$ & $5-9$ & $5-9$ & $7-11$ & $6 \cdot 5-8 \cdot 4$ & ND & $5 \cdot 5-8 \cdot 5$ & 5-9 & ND & ND & ND & $7-11$ & $6-12$ & $7 \cdot 5-11$ & ND & $5-10$ & 5-9 & $5-9$ & $5-9$ & $3-10$ & ND \\
\hline $\begin{array}{l}\text { Hydrolysis of: } \\
\text { Casein }\end{array}$ & & - & & & & & & & & & & & & & & & & & & & & & & & \\
\hline $\begin{array}{l}\text { Casein } \\
\text { Aesculin }\end{array}$ & $\begin{array}{l}- \\
+\end{array}$ & $\begin{array}{l}- \\
+\end{array}$ & $\begin{array}{l}- \\
-\end{array}$ & $\begin{array}{l}- \\
+\end{array}$ & - & - & $\begin{array}{l}- \\
-\end{array}$ & $\begin{array}{c}- \\
\mathrm{ND}\end{array}$ & $\begin{array}{l}+ \\
+\end{array}$ & $\begin{array}{l}- \\
-\end{array}$ & $\begin{array}{l}\mathrm{ND} \\
+\end{array}$ & $\begin{array}{l}+ \\
-\end{array}$ & $\begin{array}{l}- \\
-\end{array}$ & $\begin{array}{l}\mathrm{ND} \\
-\end{array}$ & $\begin{array}{l}+ \\
+\end{array}$ & $\begin{array}{c}- \\
\mathrm{ND}\end{array}$ & $\begin{array}{l}\mathrm{ND} \\
\mathrm{ND}\end{array}$ & $\begin{array}{c}- \\
\mathrm{ND}\end{array}$ & $\begin{array}{l}+ \\
-\end{array}$ & $\begin{array}{l}- \\
-\end{array}$ & $\begin{array}{l}- \\
-\end{array}$ & $\begin{array}{l}- \\
-\end{array}$ & $\begin{array}{l}\mathrm{d} \\
\mathrm{d}\end{array}$ & $\begin{array}{l}\text { ND } \\
\text { ND }\end{array}$ & $\begin{array}{l}- \\
+\end{array}$ \\
\hline Gelatin & + & + & - & - & - & - & $\mathrm{ND}$ & - & - & - & - & - & - & - & - & - & $\mathrm{ND}$ & - & - & - & - & - & d & - & - \\
\hline Starch & - & - & - & - & - & d & + & - & - & - & - & - & - & - & - & - & ND & - & - & - & - & - & - & - & + \\
\hline Tween 80 & - & + & - & - & - & + & - & $\mathrm{ND}$ & ND & - & + & + & - & - & - & - & $\mathrm{ND}$ & ND & - & - & - & - & - & $\mathrm{ND}$ & - \\
\hline Nitrate reduction & + & + & - & + & + & + & - & + & - & + & + & + & - & + & + & + & ND & + & - & - & + & + & + & - & - \\
\hline $\begin{array}{l}\text { Phenylalanine } \\
\text { deaminase }\end{array}$ & - & - & ND & - & + & - & ND & - & - & - & - & - & - & ND & - & + & - & - & - & - & - & - & - & - & + \\
\hline $\mathrm{H}_{2} \mathrm{~S}$ production & - & + & - & + & + & - & - & + & - & - & - & - & - & - & - & $\mathrm{ND}$ & $\mathrm{ND}$ & + & - & - & - & - & + & $\mathrm{ND}$ & ND \\
\hline Urease & + & + & + & + & + & + & + & ND & + & + & d & - & + & ND & - & - & - & & + & - & - & - & + & ND & - \\
\hline Growth on: & & & & & & & & & & & & & & & & & & & & & & & & & \\
\hline Citrate & ND & + & - & + & + & - & + & + & - & + & + & - & + & ND & + & + & ND & + & + & - & + & ND & + & ND & + \\
\hline Fructose & ND & - & + & + & + & + & + & + & - & + & + & - & + & $\mathrm{ND}$ & + & + & + & + & + & - & + & ND & + & ND & ND \\
\hline Glucose & + & - & + & d & - & + & + & + & - & + & + & - & + & ND & + & + & + & + & + & + & + & $\mathrm{ND}$ & + & ND & ND \\
\hline Glycerol & + & - & + & + & - & + & + & + & + & + & + & - & + & $\mathrm{ND}$ & + & + & + & + & + & ND & + & + & + & ND & ND \\
\hline Mannose & + & + & + & + & - & + & + & + & - & - & + & - & - & $\mathrm{ND}$ & + & + & - & + & - & + & + & + & + & ND & + \\
\hline Sucrose & + & + & + & + & - & - & + & + & - & + & $\mathrm{ND}$ & - & - & $\mathrm{ND}$ & + & + & + & + & - & + & - & + & + & $\mathrm{ND}$ & ND \\
\hline $\begin{array}{l}\mathrm{G}+\mathrm{C} \text { content } \\
(\mathrm{mol} \%)\end{array}$ & $60 \cdot 5$ & $58 \cdot 8-59 \cdot 1$ & 63 & $66 \cdot 7$ & $60 \cdot 4-64 \cdot 2$ & $57-58$ & $58 \cdot 2-59 \cdot 9$ & 62 & 61 & $52-55$ & $63 \cdot 2$ & $60 \cdot 9-62 \cdot 9$ & $67-68$ & 65 & $60-63$ & 66 & 66 & 65 & $62-64$ & $62-65$ & 62 & 65 & $62 \cdot 4-66$ & $55 \cdot 8$ & 56 \\
\hline
\end{tabular}

* L, Lateral; P, polar; Pe, peritrichous. 
heterogeneous group of halophilic micro-organisms and serve as a starting point for other studies. It is feasible that a comprehensive (and polyphasic) study may provide the data necessary for a more accurate classification of these organisms complementary to the phylogenetic view outlined in this study.

\section{ACKNOWLEDGEMENTS}

D. R.A. was the recipient of a fellowship from the Ministerio de Educación y Cultura, Spain. This study was supported by grants from the Ministerio de Educación y Cultura, Spain (grants 1FD97-1162 and PB98-1150), and from the Junta de Andalucía. We acknowledge Gustavo González for his valuable assistance with computers.

\section{REFERENCES}

Akagawa, M. \& Yamasato, K. (1989). Synonymy of Alcaligenes aquamarinus, Alcaligenes faecalis subsp. homari, and Deleya aesta: Deleya aquamarina comb. nov. as the type species of the genus Deleya. Int J Syst Bacteriol 39, 462-466.

Arahal, D. R., García, M. T., Ludwig, W., Schleifer, K. H. \& Ventosa, A. (2001a). Transfer of Halomonas canadensis and Halomonas israelensis to the genus Chromohalobacter as Chromohalobacter canadensis comb. nov. and Chromohalobacter israelensis comb. nov. Int J Syst Evol Microbiol 51, 1443-1448.

Arahal, D. R., García, M. T., Vargas, C., Cánovas, D., Nieto, J. J. \& Ventosa, A. (2001b). Chromohalobacter salexigens sp. nov., a moderately halophilic species that includes Halomonas elongata DSM 3043 and ATCC 33174. Int J Syst Evol Microbiol 51, 1457-1462.

Baumann, L., Baumann, P., Mandel, M. \& Allen, R. D. (1972). Taxonomy of aerobic marine eubacteria. J Bacteriol 110, 402-429.

Berendes, F., Gottschalk, G., Heine-Dobbernack, E., Moore, E. R. B. \& Tindall, B. J. (1996). Halomonas desiderata sp. nov., a new alkaliphilic, halotolerant and denitrifying bacterium isolated from a municipal sewage works. Syst Appl Microbiol 19, $158-167$

Briones, C. \& Amils, R. (2000). Nucleotide sequence of the $23 \mathrm{~S}$ rRNA from Haloferax mediterranei and phylogenetic analysis of halophilic archaea based on LSU rRNA. Syst Appl Microbiol 23, 124-131.

Cobet, A. B., Wirsen, C., Jr \& Jones, G. E. (1970). The effect of nickel on a marine bacterium, Arthrobacter marinus sp. nov. $J$ Gen Microbiol 62, 159-169.

Davis, D. H., Doudoroff, M., Stanier, R. Y. \& Mandel, M. (1969). Proposal to reject the genus Hydrogenomonas: taxonomic implications. Int J Syst Bacteriol 19, 375-390.

Dobson, S. J. \& Franzmann, P. D. (1996). Unification of the genera Deleya (Baumann et al. 1983), Halomonas (Vreeland et al. 1980), and Halovibrio (Fendrich 1988) and the species Paracoccus halodenitrificans (Robinson and Gibbons 1952) into a single genus, Halomonas, and placement of the genus Zymobacter in the family Halomonadaceae. Int J Syst Bacteriol 46, 550-558.

Dobson, S. J., James, S. R., Franzmann, P. D. \& McMeekin, T. A. (1990). Emended description of Halomonas halmophila (NCMB $\left.1971^{\mathrm{T}}\right)$. Int J Syst Bacteriol 40, 462-463.

Dobson, S. J., McMeekin, T. A. \& Franzmann, P. D. (1993). Phylogenetic relationships between some members of the genera
Deleya, Halomonas, and Halovibrio. Int J Syst Bacteriol 43, 665-673.

Duckworth, A. W., Grant, W. D., Jones, B. E., Meijer, D., Márquez, M. C. \& Ventosa, A. (2000). Halomonas magadii sp. nov., a new member of the genus Halomonas, isolated from a soda lake of the East African Rift Valley. Extremophiles 4, 53-60.

Euzéby, J. P. (1997). List of bacterial names with standing in nomenclature: a folder available on the Internet. Int $J$ Syst Bacteriol 47, 590-592. http://www.bacterio.cict.fr/

Fendrich, C. (1988). Halovibrio variabilis gen. nov. sp. nov., Pseudomonas halophila sp. nov. and a new halophilic aerobic coccoid Eubacterium from Great Salt Lake, Utah, USA. Syst Appl Microbiol 11, 36-43.

Franzmann, P. D., Burton, H. R. \& McMeekin, T. A. (1987). Halomonas subglaciescola, a new species of halotolerant bacteria isolated from Antarctica. Int J Syst Bacteriol 37, 27-34.

Franzmann, P. D., Wehmeyer, U. \& Stackebrandt, E. (1988). Halomonadaceae fam. nov., a new family of the class Proteobacteria to accommodate the genera Halomonas and Deleya. Syst Appl Microbiol 11, 16-19.

Garriga, M., Ehrmann, M. A., Arnau, J., Hugas, M. \& Vogel, R. F. (1998). Carnimonas nigrificans gen. nov., sp. nov., a bacterial causative agent for black spot formation on cured meat products. Int J Syst Bacteriol 48, 677-686.

Hebert, A. M. \& Vreeland, R. H. (1987). Phenotypic comparison of halotolerant bacteria: Halomonas halodurans sp. nov., nom. rev., comb. nov. Int J Syst Bacteriol 37, 347-350.

Huval, J. H., Latta, R., Wallace, R., Kushner, D. J. \& Vreeland, R. H. (1995). Description of two new species of Halomonas: Halomonas israelensis sp. nov. and Halomonas canadensis sp. nov. Can J Microbiol 41, 1124-1131.

James, S. R., Dobson, S. J., Franzmann, P. D. \& McMeekin, T. A. (1990). Halomonas meridiana, a new species of extremely halotolerant bacteria isolated from Antarctic saline lakes. Syst Appl Bacteriol 13, 270-277.

Jukes, T. H. \& Cantor, C. R. (1969). Evolution of protein molecules. In Mammalian Protein Metabolism, pp. 21-132. Edited by H. N. Munro. New York: Academic Press.

Ludwig, W. \& Schleifer, K. H. (1995). Bacterial phylogeny based on $16 \mathrm{~S}$ and $23 \mathrm{~S}$ rRNA sequence analysis. FEMS Microbiol Rev 15, $155-173$.

Ludwig, W. \& Strunk, O. (1996). ARB - a software environment for sequence data. http://www.mikro.biologie.tu-muenchen. $\mathrm{de} / \mathrm{pub} / \mathrm{ARB} /$ documentation/arb.ps

Ludwig, W., Kirchhof, G., Klugbauer, N. \& 12 other authors (1992). Complete 23S ribosomal RNA sequences of Grampositive bacteria with a low DNA G+C content. Syst Appl Microbiol 15, 487-501.

Ludwig, W., Rosselló-Mora, R., Aznar, R. \& 14 other authors (1995). Comparative sequence analyses of $23 \mathrm{~S}$ rRNA from Proteobacteria. Syst Appl Microbiol 18, 164-188.

Ludwig, W., Strunk, O., Klugbauer, S., Klugbauer, N., Weizenegger, M., Neumaier, J., Bachleitner, M. \& Schleifer, K. H. (1998). Bacterial phylogeny based on comparative sequence analysis. Electrophoresis 19, 554-568.

Martínez-Murcia, A. J., Harland, N. M. \& Collins, M. D. (1993). Phylogenetic analysis of some leuconostocs and related organisms as determined from large-subunit rRNA gene sequences: assessment of congruence of small- and largesubunit rRNA derived trees. J Appl Bacteriol 74, 532-541.

Mellado, E., Moore, E. R. B., Nieto, J. J. \& Ventosa, A. (1995). Phylogenetic inferences and taxonomic consequences of $16 \mathrm{~S}$ 
ribosomal DNA sequence comparison of Chromohalobacter marismortui, Volcaniella eurihalina, and Deleya salina and reclassification of $V$. eurihalina as Halomonas eurihalina comb. nov. Int J Syst Bacteriol 45, 712-716.

Mormile, M. R., Romine, M. F., García, M. T., Ventosa, A., Bailey, T. J. \& Peyton, B. M. (1999). Halomonas campisalis sp. nov., a denitrifying, moderately haloalkaliphilic bacterium. Syst Appl Microbiol 22, 551-558.

Okamoto, T., Taguchi, H., Nakamura, K., Ikenaga, H., Kuraishi, H. \& Yamasato, K. (1993). Zymobacter palmae gen. nov., sp. nov., a new ethanol-fermenting peritrichous bacterium isolated from palm sap. Arch Microbiol 160, 333-337.

Owen, R. J. \& Pitcher, D. (1985). Current methods for estimating DNA base composition and levels of DNA-DNA hybridization. In Chemical Methods in Bacterial Systematics, pp. 67-93. Edited by M. Goodfellow \& E. Minnikin. London: Academic Press.

Quesada, E., Ventosa, A., Ruiz-Berraquero, F. \& RamosCormenzana, A. (1984). Deleya halophila, a new species of moderately halophilic bacteria. Int J Syst Bacteriol 34, 287-292.

Quesada, E., Valderrama, M. J., Bejar, V., Ventosa, A., Gutiérrez, M. C., Ruiz-Berraquero, F. \& Ramos-Cormenzana, A. (1990). Volcaniella eurihalina gen. nov., sp. nov., a moderately halophilic nonmotile gram-negative rod. Int J Syst Bacteriol 40, 261-267.
Romano, I., Nicolaus, B., Lama, L., Manca, M. C. \& Gambacorta, A. (1996). Characterization of a haloalkalophilic strictly aerobic bacterium, isolated from Pantelleria island. Syst Appl Microbiol 19, 326-333.

Rosenberg, A. (1983). Pseudomonas halodurans sp. nov., a halotolerant bacterium. Arch Microbiol 136, 117-123.

Saitou, N. \& Nei, M. (1987). The neighbor-joining method: a new method for reconstructing phylogenetic trees. Mol Biol Evol 4, 406-425.

Sallen, B., Rajoharison, A., Desvarenne, S., Quinn, F. \& Mabilat, C. (1996). Comparative analysis of $16 \mathrm{~S}$ and $23 \mathrm{~S}$ rRNA sequences of Listeria species. Int J Syst Bacteriol 46, 669-674.

Valderrama, M. J., Quesada, E., Bejar, V., Ventosa, A., Gutiérrez, M. C., Ruiz-Berraquero, F. \& Ramos-Cormenzana, A. (1991). Deleya salina $\mathrm{sp}$. nov., a moderately halophilic gram-negative bacterium. Int J Syst Bacteriol 41, 377-384.

Ventosa, A., Gutiérrez, M. C., García, M. T. \& Ruiz-Berraquero, F. (1989). Classification of "Chromobacterium marismortui" in a new genus, Chromohalobacter gen. nov., as Chromohalobacter marismortui comb. nov., nom. rev. Int J Syst Bacteriol 39, 382-386.

Vreeland, R. H., Litchfield, C. D., Martin, E. L. \& Elliot, E. (1980). Halomonas elongata, a new genus and species of extremely salttolerant bacteria. Int J Syst Bacteriol 30, 485-495. 